\title{
Probability of pregnancy in beef heifers
}

\author{
[Probabilidade de prenhez em novilhas de corte] \\ D.P. Faria ${ }^{1}$, M.D. da Costa $^{1 *}$, F.S.S. Raidan ${ }^{1}$, J.R.M. Ruas ${ }^{2}$, V.R.R. Júnior ${ }^{1}$, \\ F.L.B. Toral ${ }^{3}$, I. Aspiazú ${ }^{1}$ \\ ${ }^{1}$ Universidade Estadual de Montes Claros - Unimontes - Janaúba, MG \\ ${ }^{2}$ Empresa de pesquisa Agropecuária de Minas Gerais - EPAMIG - Felixlândia, MG \\ ${ }^{3}$ Escola de Veterinária - UFMG - Belo Horizonte, MG
}

\begin{abstract}
This study aimed to evaluate the influence of initial weight, initial age, average daily gain in initial weight, average daily gain in total weight and genetic group on the probability of pregnancy in primiparous females of the Nellore, $1 / 2$ Simmental $+1 / 2$ Nellore, and $3 / 4$ Nellore $+1 / 4$ Simmental genetic groups. Data were collected from the livestock file of the Farpal Farm, located in the municipality of Jaíba, Minas Gerais State, Brazil. The pregnancy diagnosis results (success $=1$ and failure $=0$ ) were used to determine the probability of pregnancy that was modeled using logistic regression by the Proc Logistic procedure available on SAS (Statistical..., 2004) software, from the regressor variables initial weight, average daily gain in initial weight, average daily gain in total weight, and genetic group. Initial weight (IW) was the most important variable in the probability of pregnancy in heifers, and 1-kg increments in IW allowed for increases of $5.8,9.8$ and $3.4 \%$ in the probability of pregnancy in Nellore, $1 / 2$ Simmental + $1 / 2$ Nellore and, 3/4 Nellore $+1 / 4$ Simmental heifers, respectively. The initial age influenced the probability of pregnancy in Nellore heifers. From the estimates of the effects of each variable it was possible to determine the minimum initial weights for each genetic group. This information can be used to monitor the development of heifers until the breeding season and increase the pregnancy rate.
\end{abstract}

Keywords: average daily gain, beef cattle, breeding season, pregnancy rate

\section{RESUMO}

Objetivou-se avaliar a influência do peso inicial, idade inicial, ganho médio diário em peso inicial, ganho médio diário em peso total e grupo genético sobre a probabilidade de prenhez de fêmeas primíparas da raça Nellore, $1 / 2$ Simental + 1/2 Nelore e 3/4 Nelore + 1/4 Simental. Os dados analisados foram do arquivo zootécnico da Fazenda Farpal, localizada no município de Jaíba, Minas Gerais. O resultado do diagnóstico de gestação (sucesso=1 e insucesso=0) foi utilizado para determinar a probabilidade de prenhez que foi modelada por meio de regressão logística pelo procedimento Logistic disponível no SAS, a partir das variáveis regressoras peso inicial, ganho médio diário em peso inicial, ganho médio diário em peso total e grupo genético. O peso inicial foi a variável de maior relevância na probabilidade de prenhez de novilhas e incrementos de $1,0 \mathrm{~kg}$ no peso inicial possibilitaram acréscimos de 5,8; 9,8 e 3,4\% na probabilidade de prenhez de novilhas Nelore, 1/2 Simental + 1/2 Nelore e 3/4 Nelore + $1 / 4$ Simental, respectivamente. Entretanto o ganho médio diário em peso inicial e ganho médio diário em peso total não apresentaram efeito significativo na probabilidade de prenhez das novilhas. A idade inicial influenciou a probabilidade de prenhez das novilhas Nelore. A partir das estimativas dos efeitos de cada variável, foi possível determinar o peso inicial mínimo para cada grupo genético. Essa informação pode ser usada para monitorar o desenvolvimento de novilhas até a estação de monta $e$ aumentar a taxa de prenhez.

Palavras-chave: estação de monta, fertilidade, gado de corte, ganho médio diário

Recebido em 5 de agosto de 2013

Aceito em 9 de setembro de 2014

*Autor para correspondência (corresponding author):

E-mail: dulcineia.costa@unimontes.br 


\section{INTRODUCTION}

Productive efficiency is vital for the profitability of beef cattle farming, and increased production in $\mathrm{kg}$ of live weight or $\mathrm{kg}$ of live weight $\mathrm{ha}^{-1}$ year $^{-1}$ depends on the reproductive rates of the herd (Barbosa et al., 2010). The birth rate refers to the number of calves born alive according to the total number of breeding females, evaluated over a given period, whereas the pregnancy rate is the percentage of these females which became pregnant. These indicators quantify the reproductive efficiency of the system (Menezes et al., 2010).

Increasing birth rate by one percentage point and reducing ages of mating and slaughter by one year resulted in average increases in production per hectare of $0.84 \%, 9.19 \%$ and $8.11 \%$ and in the outcome rates of $0.88 \%, 8.81 \%$ and $19.7 \%$, respectively (Lampert et al. 2012).

In production systems, the pregnancy rate is still one of the variables with the greatest impact on the evaluation of reproductive performance and contributes considerably to the bioeconomic efficiency (Barcellos et al., 2006). Thus, quantifying the most relevant factors influencing this rate is crucial for the establishment of measures to optimize the number of pregnant females at the end of the breeding season.

According to Short et al. (1994), the age and weight at which the heifer reaches puberty are determinant factors of reproductive rates and these, in turn, vary according to the genetic composition, feeding level and/or, weight gain rate from the post-weaning to first fertile estrus interval. To obtain satisfactory economic return, the determinant factors of reproductive rates of the herd must be understood and managed in a systemic approach, because there is no single formula or recommendation that can be widely applied in different production systems (Barbosa et al., 2010).

Given the importance of pregnancy rate in the financial profitability of the beef cattle production system, the aim was to evaluate the influence of age, weight, and genetic group on the probability of pregnancy in primiparous females raised in the Cerrado region of Brazil.

\section{MATERIAL AND METHODS}

Data pertaining to 148 heifers (59 Nellore, 46 1/2 Simmental $+1 / 2$ Nellore, and $433 / 4$ Nellore $+1 / 4$ Simmental), obtained from the livestock files of the Farpal Farm in the municipality of Jaíba, Minas Gerais State, Brazil, were used in this study. The climate in this region is an Aw according to Köppen's classification, characterized by dry winters and rainy summers, with an average annual precipitation of $800 \mathrm{~mm}$, irregularly distributed from November to April, and an average annual temperature of $26^{\circ} \mathrm{C}$ and maximum temperature of $40^{\circ} \mathrm{C}$ (Brasil, 1992).

The heifers were born in 2001 and were raised in a pasture or stocker (backgrounding) program. During the summer months, from November to April, they received forage via pastures, predominantly Brachiaria decumbens and small areas of Brachiaria brizantha and Cenchrus ciliaris, plus mineral supplementation. In the winter months, from May to October, besides the forage and mineral sources, protein and energy supplementation was provided according to the growth phase.

The breeding season began on December 1, 2002 and ended on March 31, 2003, using Nellore bulls in natural mounting. Heifers were aged approximately 12 months at the beginning of the breeding season. Weighing was performed before the start of the breeding season (in November) and monthly until the pregnancy diagnosis, which occurred in May, 60 days after the end of the breeding season.

The result of the pregnancy diagnosis (success $=1$ and failure $=0$ ) was used to study the probability of pregnancy, which was modeled by logistic regression, considering the following general model:

$$
\ln \left(\frac{p_{i j k l m n}}{1-p_{i j k l m n}}\right)=\beta_{0}+\beta_{1} x_{1 i}+\beta_{2} x_{2 j}+\beta_{3} x_{3 k}+\beta_{4} x_{4 l}+\beta_{5} x_{5 m}+\varepsilon_{i j k l m n} .
$$

Where $p_{i j k l m n}$ is the probability of pregnancy of animal $n$, with initial weight $i\left(x_{1 i}\right)$, initial age $j\left(x_{2 j}\right)$, average daily gain in initial weight $k\left(x_{3 k}\right)$, average daily gain in total weight $l\left(x_{4 l}\right)$ and genetic group $m\left(x_{5 m}\right) ; \beta_{0}$ is a general constant present in all observations; $\beta_{h}(h=1,2,3,4$ and 5) are the regression coefficients associated with the regressor variables $X_{h}$; and $\varepsilon_{i j k l m n}$ is the random error associated with each observation. 
The weight was divided into two phases: the initial period (1-40 days), and the total period (1-120 days), to make sure that the weight gain in the early breeding season would increase the likelihood of heifer pregnancy at the time of pregnancy diagnosis, as described by Barcellos et al. (2006).

The parameter estimates were obtained by the maximum likelihood method and the final model was accomplished using the logistic regression procedure (Logistic from Statistical Analysis System - SAS ${ }^{\circledR}$ ).

Initially the Stepwise option identifies the regressor variable that solely provides the best fit (highest R2). Then, another variable that results in the best fit model with two variables is included. The significance of the regression coefficients is considered to assess the need for exclusion of some variable. The procedures for inclusion of a new variable, assessment of the significance and necessity of excluding variables are repeated until there are no more variables to be added to or deleted from the model (Freund and Littell, 2000).

The odds ratio $\left(\frac{p(\text { sucess })}{p(\text { failure })}\right)$ associated with each variable was estimated by $e^{\hat{\beta}_{h}}$ and defines the change in odds ratio when there is a change of one unit of the regressor variable (Freund and Littell, 2000).

The statistic used to assess the validity of the models was the percentage of observationspredictions concordant pairs. This procedure consists of comparing the probabilities among the observed and predicted responses considering all possible pairs of observations $\left(y_{i}, y_{j}\right.$ onde $\left.i \neq j\right)$, so that the observed responses for $y_{i}$ 's are equal to one (success) and those observed for $y_{j}$ 's are equal to zero (failure). Thus, $n_{i} \times n_{j}$ pairs of observations (success $\times$ failure in pregnancy diagnosis) were formed and classified as concordant when $\hat{P}_{i}>\hat{P}_{j}$, discordant when $\hat{P}_{i}<\hat{P}_{j}$, and tied if $\hat{P}_{i}=\hat{P}_{j}$. The proportion for each model was calculated in relation to the total $n_{i} \times n_{j}$ pairs (Bergmann and Hohenboken, 1992).

The significance level for the effects of the sources of variation was calculated by the likelihood ratio test, which consists of comparing the value of the likelihood function obtained in the reduced model, which considers only the constant, and the value of the function in the full model, which includes the regressor variable as well as the intercept.

\section{RESULTS AND DISCUSSION}

Except for the initial average daily gain (ADG1), the traits showed low instability, with coefficients of variation between 8.72 and $17.14 \%$ (Tab.1). For the average daily gain in initial weight, a coefficient of variation greater than $40 \%$ was observed for all genetic groups. Variations in weight of heifers during the breeding season can be explained by additive and non-additive genetic differences (Schafhäuser Junior et al., 2003). The greater movement of the females and the less time spent grazing when they come in estrus also corroborate the variation in this factor (Soares et al., 2008).

The mean pregnancy rate was $68.24 \%$. This value is within the range observed in the literature, which ranges from 63.93\% (Barcellos et al., 2006, for Hereford heifers) to 77\% (Pilau and Lobato, 2008, for Angus heifers). According to these authors, the ideal beef cow is the one that in a 12-month period becomes pregnant in the first weeks of the breeding season, gives birth and weans a healthy calf and repeats pregnancy at the beginning of the subsequent reproductive period. This requires efficient nutritional support and attention to possible impairment of the performance due to the interaction between genotype and environment.

The initial weight significantly influenced the probability of pregnancy when the data were analyzed as a group (general analysis) or when analyses were performed separately for each genetic group (Tab. 2). The odds ratio for the initial weight was higher than one, indicating that the increase of $1 \mathrm{~kg}$ in the initial live weight of heifers would increase the probability of pregnancy for Nellore, $1 / 2$ Simmental $+1 / 2$ Nellore, and $3 / 4$ Nellore $+1 / 4$ Simmental by 5.8, 9.8 and $3.4 \%$ respectively. In the general analysis, an odds ratio of 1.057 was estimated for initial weight, i.e., a $5.7 \%$ increase in the probability of pregnancy for each kilogram of increase in live weight at the beginning of the breeding season. 
Faria et al.

Table 1. Descriptive statistics of the regressor variables of the probability of pregnancy in beef heifers during the breeding season in the Cerrado region

\begin{tabular}{|c|c|c|c|c|}
\hline Variable $^{1}$ & $\begin{array}{l}\text { Mean } \\
(\mathrm{kg})\end{array}$ & $\begin{array}{c}\text { Standard deviation } \\
(\mathrm{kg})\end{array}$ & $\begin{array}{l}\text { Maximum } \\
(\mathrm{kg})\end{array}$ & $\begin{array}{c}\text { Minimum } \\
(\mathrm{kg})\end{array}$ \\
\hline \multicolumn{5}{|c|}{ Overall mean $(n=148)$} \\
\hline IW (kg) & 258.38 & 28.79 & 362.00 & 180.00 \\
\hline IA (months) & 12.36 & 1.56 & 18.60 & 9.10 \\
\hline ADG1 (g) & 788.65 & 333.68 & 1866.67 & 0.00 \\
\hline ADGT (g) & 654.07 & 109.43 & 954.54 & 416.66 \\
\hline \multicolumn{5}{|c|}{ Nellore $(n=59)$} \\
\hline IW (kg) & 249.10 & 22.15 & 360.00 & 180.00 \\
\hline IA (months) & 12.33 & 1.42 & 17.00 & 9.10 \\
\hline ADG1 (g) & 792.81 & 344.70 & 1866.67 & 0.00 \\
\hline ADGT (g) & 643.55 & 110.31 & 954.56 & 431.82 \\
\hline \multicolumn{5}{|c|}{$1 / 2$ Simmental $+1 / 2$ Nellore $(n=46)$} \\
\hline IW (kg) & 274.56 & 23.96 & 362.00 & 220.00 \\
\hline IA (months) & 13.04 & 1.85 & 18.60 & 10.20 \\
\hline ADG1 (g) & 793.47 & 341.89 & 1666.67 & 181.81 \\
\hline ADGT (g) & 654.81 & 111.27 & 909.09 & 416.66 \\
\hline \multicolumn{5}{|c|}{$3 / 4$ Nellore $+1 / 4$ Simmental $(n=43)$} \\
\hline IW (kg) & 253.79 & 23.96 & 343.00 & 210.00 \\
\hline IA (months) & 11.69 & 1.07 & 13.70 & 10.70 \\
\hline ADG1 (g) & 777.80 & 316.55 & 1363.64 & 60.61 \\
\hline ADGT (g) & 667.72 & 107.22 & 939.40 & 477.27 \\
\hline
\end{tabular}

${ }^{1} \mathrm{IW}=$ initial weight, IA = initial age, ADG1 = average daily gain in initial weight (1-40 days), ADGT = average daily gain in total weight (1-120 days).

Table 2. Estimate of the parameters used in modeling the probability of pregnancy in beef heifers during the breeding season in the Cerrado region

\begin{tabular}{|c|c|c|c|c|c|c|c|c|}
\hline \multirow[t]{2}{*}{$\begin{array}{c}\text { Regression } \\
\text { variables }\end{array}$} & \multicolumn{2}{|c|}{ Regression coefficient } & \multirow{2}{*}{$\begin{array}{l}\begin{array}{l}\text { Odds } \\
\text { ratio }\end{array} \\
\text { Odds } \\
\text { ratio }\end{array}$} & \multirow[t]{2}{*}{$\begin{array}{c}\text { Confidence } \\
\text { interval }\end{array}$} & \multicolumn{2}{|c|}{$\%$ pairs } & \multirow[t]{2}{*}{ Suc/Fail } & \multirow[t]{2}{*}{ P-value } \\
\hline & $\hat{\beta}_{0}$ & $\hat{\beta}_{1}$ & & & Conc & Disc & & \\
\hline \multicolumn{9}{|c|}{ Overall mean } \\
\hline IW & -13.2799 & 0.05580 & 1.057 & $1.031-1.085$ & 74.3 & 22.6 & $101 / 47$ & $<0.001$ \\
\hline IA & -2.5843 & 0.27360 & 1.315 & $1.013-1.706$ & 56.1 & 36.2 & $101 / 47$ & 0.0395 \\
\hline ADG1 & 0.8317 & -0.00008 & 1.000 & $0.999-1.001$ & 46.1 & 44.9 & $101 / 47$ & 0.8733 \\
\hline ADGT & -0.1272 & 0.00137 & 1.001 & $\begin{array}{l}0.998-1.005 \\
\text { Nellore }\end{array}$ & 53.0 & 43.6 & $101 / 47$ & 0.4062 \\
\hline IW & -14.1786 & 0.05670 & 1.058 & $1.013-1.106$ & 68.4 & 28.5 & 28/31 & 0.0118 \\
\hline IA & -3.7714 & 0.29730 & 1.346 & $0.908-1.995$ & 60.9 & 34.3 & 28/31 & 0.1386 \\
\hline ADG1 & -0.0591 & -0.00005 & 1.000 & $0.998-1.001$ & 44.5 & 43.7 & 28/31 & 0.9437 \\
\hline ADGT & -1.9843 & 0.00292 & 1.003 & $0.998-1.008$ & 56.7 & 40.8 & $28 / 31$ & 0.2367 \\
\hline \multicolumn{9}{|c|}{$1 / 2$ Simmental + 1/2 Nellore } \\
\hline IW & -20.7249 & 0.09320 & 1.098 & $1.000-1.205$ & 91.5 & 8.5 & $43 / 3$ & 0.0502 \\
\hline IA & -1.4437 & 0.32430 & 1.383 & $0.549-3.483$ & 57.4 & 41.9 & $43 / 3$ & 0.4913 \\
\hline ADG1 & 2.7110 & 0.00006 & 1.000 & $0.997-1.003$ & 36.4 & 20.2 & $43 / 3$ & 0.9724 \\
\hline ADGT & 2.3260 & 0.00052 & 1.001 & $0.990-1.011$ & 38.0 & 42.6 & $43 / 3$ & 0.9245 \\
\hline \multicolumn{9}{|c|}{ 3/4 Nellore $+1 / 4$ Simmental } \\
\hline IW & -7.5831 & 0.03370 & 1.034 & $0.995-1.075$ & 62.8 & 29.2 & $30 / 13$ & 0.0873 \\
\hline IA & 0.3528 & 0.04140 & 1.042 & $0.562-1.932$ & 36.7 & 34.1 & $30 / 13$ & 0.8954 \\
\hline ADG1 & 1.000 & -0.00021 & 1.000 & $0.998-1.002$ & 48.5 & 47.2 & $30 / 13$ & 0.8439 \\
\hline ADGT & 1.8362 & -0.00149 & 0.999 & $0.992-1.005$ & 49.2 & 45.1 & $30 / 13$ & 0.6327 \\
\hline
\end{tabular}

IW = initial weight, IA = initial age; ADG1 = average daily gain in initial weight (1-40 days), ADGT = average daily gain in total weight $(1-120$ days); Suc/Fail $=$ success/failure; Conc. = concordants; Disc. $=$ discordants. 
These results agree with those described by Barcellos et al. (2006). These authors classified Hereford heifers into two groups, according to the weight (264 and $301 \mathrm{~kg}$ as light and 285 and $331 \mathrm{~kg}$ as heavy) and subdivided groups according to the age at the beginning of the breeding season (18 and 24 months).

Grecellé et al. (2006) concluded that the increase of $10 \mathrm{~kg}$ in weight at the beginning of the breeding season increased the probability of pregnancy in $1 / 2$ Hereford $+1 / 2$ Nellore heifers by $13.3 \%$ and the weight that provided the highest probability of pregnancy was $333 \mathrm{~kg}$. The initial weight of the heifers that allowed for obtaining probability of pregnancy of up to $90 \%$, obtained from the substitution of the estimated regression coefficients of the model set, were 289, 246 and $290 \mathrm{~kg}$ for Nellore, $1 / 2$ Simmental $+1 / 2$ Nellore, and $3 / 4$ Nellore $+1 / 4$ Simmental, respectively. Among genetic groups, $1 / 2$ Simmental $+1 / 2$ Nellore heifers showed high probability of pregnancy with less weight. This fact may be due to the younger age at the beginning of reproductive life in this genetic group, as well as the individual heterosis for this variable (Lemos et al., 1992).

From these obtained weights it is possible to develop nutritional strategies that allow heifers to reach the minimum weight at the beginning of the season. From weaning, heifers can be managed in areas with higher availability and quality of pasture to gain enough weight to reach the minimum values. To foster the selection of superior females for breeding, the beginning of the breeding season could also be postponed to January, increasing the time available for heifers to consume better quality forage, which is available after the start of the rainy season. Thus, those heifers which reach the minimum weight can be challenged during the breeding season and those that remain empty at the end of the season would not be selected to be mothers of the next generation. The protein-energy supplementation is another strategy that can be used to optimize the average daily weight gain of heifers in the period prior to the breeding season.

Puberty in heifers occurs after a certain level of somatic development — the "critical minimum weight" - which, when achieved, stops the negative-feedback effect of estradiol on the pituitary gland, hypothalamus, or both, thereby providing an increase in the pulsatile frequency of the luteinizing hormone (LH) and subsequent ovulation (Gottschall et al., 2011).

In this study, the effect of initial age was significant in Nellore heifers and when all genetic groups were analyzed as a group, with odds ratios of 1.346 , and 1.315, which implies elevations of 34.6 and $31.5 \%$, respectively, in the probability of pregnancy for each one-month increase in the age of the animals entering the breeding season. Heifers with younger age at first calving indicate greater reproductive efficiency and provide greater profit by having reduced maintenance costs (Machado et al., 2001). Therefore, it is necessary to adopt nutritional strategies that conciliate age and weight at the beginning of the breeding season that are suitable for increasing the female's lifetime by initiating reproductive life earlier, yet with less risk of becoming inefficient in the second breeding season.

The average daily gain in initial weight (ADG1) and average daily gain in total weight (ADGT) showed no significant effect on the probability of pregnancy in heifers. Grecellé et al. (2006), unlike the present study, observed a significant effect of ADG and concluded that a daily weight gain of $100 \mathrm{~g} \mathrm{day}^{-1}$ during the breeding season increased the chance of conception by $20 \%$. However, these authors stated that there was great variation in ADG and the animals that entered the breeding season with adequate weight and maintained this weight during the breeding season showed satisfactory pregnancy rates. On the other hand, Batista et al. (2012) concluded that the management that provides weight gain to the animals during the breeding season will increase the probability of pregnancy. Also, animals likely to achieve satisfactory pregnancy need to have a body condition score around 6.0 at the beginning of the breeding season and above that at the end of the breeding season. In the present study, the regressor variable ADG1 showed a coefficient of variation of $42.32 \%$, and the heifers with highest initial weight, $1 / 2$ Simmental $+1 / 2$ Nellore (average $274.56 \mathrm{~kg}$ ), achieved the highest pregnancy rate among the considered groups, 93.5\%. The heifers from the three genetic groups increased their pregnancy rate according to the initial weight until reaching a plateau (Figure 1). 

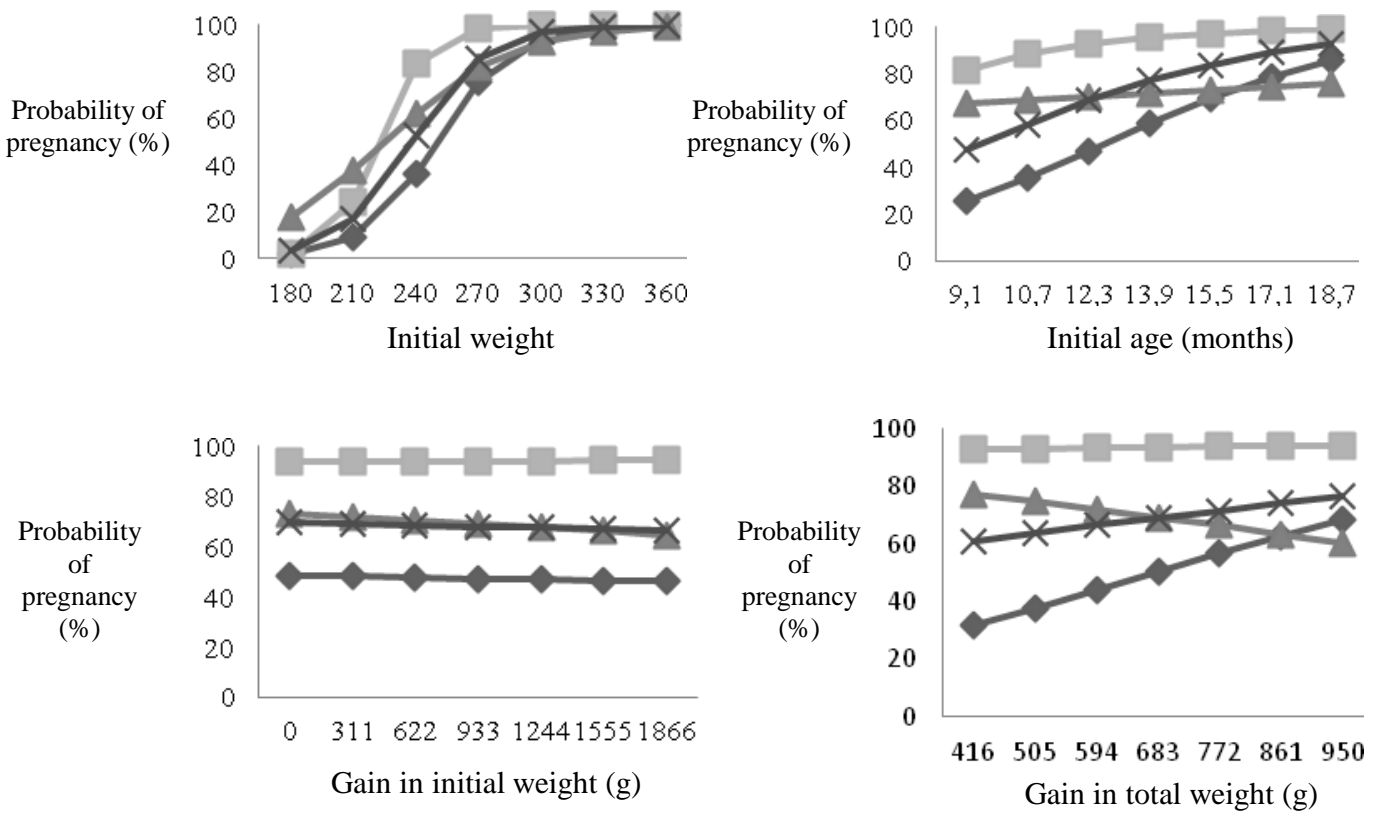

$$
\because \text { Nellore }=1 / 2 \text { Simmental }+1 / 2 \text { Nellore }=\text { Nellore }+1 / 4 \text { Simmental } \rightarrow \text { Means }
$$

Figure 1. Probability of pregnancy in Nellore and Nellore + Simmental crossbred heifers according to initial weight, initial age, average daily gain in initial weight (ADG1) and average daily gain in total weight (ADGT).

The weight at the beginning of this plateau can be considered the ideal weight for the beginning of reproductive life, given that from that point weight gain does not imply greater probability of pregnancy, as observed in this study and also by Barcellos et al. (2006). Therefore, it would be possible to work with an optimal measure of weight.

\section{CONCLUSIONS}

The weight at the beginning of the breeding season is the variable with the greatest impact on the probability of pregnancy during the first mating of beef heifers. Genetic group and initial age also influence the probability of pregnancy in beef heifers. $1 / 2$ Simmental $+1 / 2$ Nellore heifers can reach the maximum level of pregnancy in the breeding season with lower initial weight when compared with the Nellore and $3 / 4$ Nellore $+1 / 4$ Simmental groups.

\section{ACKNOWLEDGEMENTS}

The authors thank Foundation for Research Support of the State of Minas Gerais (FAPEMIG) and CAPES for the financial support, and Farpal Farm for providing the data.

\section{REFERENCES}

BARBOSA, F.A.; GRAÇA, D.S.; ANDRADE, V.J. et al. Produtividade e eficiência econômica de sistemas de produção de cria, recria e engorda de bovinos de corte na região sul do estado da Bahia. Arq. Bras. Med. Vet. Zootec, v.62, p.677685, 2010.

BARCELLOS, J.O.J.; SILVA, M.D.; PRATES, E.R.; COSTA, E.C. Taxas de prenhez em novilhas de corte acasaladas aos 18 e 24 meses de idade. Arq. Bras. Med. Vet. Zootec., v.58, p.1168-1173, 2006. 
BATISTA, D.S.N.; ABREU, U.G.P.; FERRAZ FILHO, P.B.; ROSA, A.N. Indices reprodutivos do rebanho Nelore da fazenda Nhumirim, Pantanal da Nhecolândia. Acta Sci. Anim. Sci., v.34, p.71-76, 2012.

BERGMANN, J.A.G.; HOHENBOKEN, W.D. Prediction of fertility from calfhood traits of Angus and Simenthal heifers. J. Anim. Sci., v.70, p.2611-2621, 1992.

BRASIL. Ministério da Agricultura e Reforma Agrária. Secretaria Nacional de Irrigação. Departamento Nacional de Meteorologia. Normais climatológicas: 1961-1990. Brasília, 1992. 84p.

FREUND, R.J.; LITTELL, R.C. SAS ${ }^{\circledR}$ System for Regression. SAS Institute, 2000. 3.ed. SAS Institute Inc, Cary, NC. 235p.

GRECELLÉ, R.A.; BARCELLOS, J.O.J.; BRACCINI NETO, J. et al. Taxa de prenhez de vacas Nelore $x$ Hereford em ambiente subtropical sob restrição alimentar. Rev. Bras. Zootec., v.35, p.1423-1430, 2006.

GOTTSCHALL, C.S.; ALMEIDA, M.R de; CANELLAS, L. Manejo Reprodutivo de novilhas - Peso e idade ao primeiro acasalamento. A Hora Vet., v.183, p.28-34, 2011.

LAMPERT, V.N.; BARCELLOS, J.O.J.; KLIEMANN NETO, F.J. et al. Development and application of a bioeconomic efficiency index for beef cattle production in Rio Grande do Sul, Brazil. Rev. Bras. Zootec., v.41, p.775-782, 2012.

LEMOS, A.M.; MADALENA, F.E.; TEODORO, R.L. et al. Comparative performance of six Holstein-Friesian x Guzera grades in Brazil. 5. Age at first calving. Rev. Bras. Zootec., v.15, p.73-83, 1992.
MACHADO, P.F.A.; BERGMANN, J.A.G.; PEREIRA, J.C.C.; SILVA, M.A. Predição da taxa de gestação de novilhas da raça Nelore acasaladas com um ano de idade. Arq. Bras. Med. Vet. Zootec., v.53, p.1-10, 2001.

MENEZES, L.M.; BRAUNER, C.C.; PIMENTEL, M.A. Efeitos da bioestimulação sobre a performance reprodutiva em bovinos de corte. Arch. Zootec., v.59, p.1-13, 2010.

PILAU, A.; LOBATO, J.F.P. Manejo de novilhas prenhes aos 13/15 meses de idade em sistemas a pasto. Rev. Bras. Zootec., v.37, p.1271-1279, 2008.

STATISTICAL Analysis System - SAS. User's guide. Version 9.1. Cary: Statistical Analysis System Institute, 2003.

SOARES, A.F.C.; FAGUNDES, N.S.; NASCIMENTO, M.R.B.M. et al. Influência da bioestimulação sobre as características ovarianas e a taxa de prenhez em novilhas nelore. Rev. Bras. Saúde Prod. Anim., v.9, p.834-838, 2008.

SCHAFHÄUSER JUNIOR, J.; MANCIO, A.B.; FONTES, C.A.A. et al. Desempenho reprodutivo de novilhas com diferentes graus de musculosidade. Rev. Fac. Zootec. Vet. Agron., v.10, p.186-202, 2003.

SHORT, R.E.; STAIGMILLER, R.B.; BELLOWS, R.A.; GREER, R.C. Breeding heifers at one year of age: biological and economic considerations. In: FIELDS, M.J.; SAND, R.S. (Eds.) Factors affecting calf crop. GAINESVILLE: CRC Press, 1994. p.55- 68. 